\title{
Peran Pemerintah Aceh dalam Penanganan Konflik Keagamaan antar Mazhab Islam
}

\section{T. Saifullah', Fauzah Nur Aksa ${ }^{2}$, Albert Alfikri³}

Dosen Fakultas Hukum Universitas Malikussaleh

tsaifuillah@unimal.ac.id

\begin{abstract}
Penelitian ini mengkaji tentang peranan pemerintah daerah Aceh dalam menangani konflik keagamaan antar mazhab Islam. Secara sosiologis, konflik keagamaan bisa didefinisikan sebagai pertentangan antara dua orang atau lebih atas kepentingan, tujuan, dan pemahaman yang membawa doktrin agama sebagai alasan konflik. Suatu konflik sosial tidak serta merta terjadi kecuali diawali dengan adanya potensi yang mengendap di dalam masyarakat dan kemudian berkembang, memanas, menjadi ketegangan, dan pada akhirnya memuncak menjadi konflik fisik sebagai akibat dari adanya pemicu. Dalam konteks Aceh, konflik keagamaan tersebut terungkap dari pertentangan antar mazhab Islam yang menjelma dalam kasus-kasus pergantian kepengurusan mesjid secara paksa yang kadang diasosiasikan sebagai kasus perebutan mesjid. Secara sederhana, tujuan dari penelitian ini adalah untuk melihat bagaimana peran pemerintah daerah Aceh dalam menangani konflik keagamaan antar sesama umat Islam yang terkotak-kotak dalam mazhab. Penelitian ini merupakan kajian hukum normatif-empiris dengan pendekatan kualitatif. Hasil penelitian menunjukkan bahwa pemerintah telah melakukan upaya-upaya untuk menciptakan kerukunan antar umat Islam di Aceh, diantaranya melalui forum kajian keagamaan, temu ilmiah, kegiatan sosial keagamaan antar kelompok Islam. Selain dari itu organisasi keagamaan seperti MPU Aceh, NU, Muhammadiah dan lainnya telah melakukan upaya untuk mencari titik temu terhadap perbedaan-perbedaan mazhab fikih yang ada dalam masyarakat Aceh. Meskipun demikian terdapat indikasi bahwa mazhab syafi'iyah dan asy'ariyah mendapat dukungan lebih dari pada mazhab lain dari pemerintah Aceh yang dapat dilihat dalam sejumlah Perda dan Surat Perintah Gubernur.
\end{abstract}

\section{Keywords:}

Peran Pemerintah, Aceh, Konflik Keagamaan, Mazhab Islam 


\section{A. PENDAHUluan}

Di Indonesia konflik-konflik dalam masyarakat masih menjadi isu yang belum terselesaikan, baik konflik yang bersifat vertikal maupun horizontal. Sepanjang tahun 2019 sebagai contoh tercatat setidaknya ada sebanyak 26 konflik sosial skala besar yang terjadi di Indonesia (Tempo, 2019). Dari jumlah tersebut 4 diantaranya yang paling banyak memakan korban jiwa, yaitu konflik sosial yang terjadi di Buton Provinsi Sulawesi Tenggara pada bulan Juni 2019, kerusuhan sosial yang terjadi di Papua dan Papua Barat pada tanggal 19 dan 29 Agustus 2019, konflik sosial di Wamena Kabupaten Jayawijaya pada tanggal 23 September 2019, dan konflik sosial di Kabupaten Penajam Paser Utara Provinsi Kalimantan Timur pada tanggal 16 Oktober 2019. Selain dari itu, masih ada puluhan konflik sosial skala kecil lainnya yang sebenarnya tidak bisa diabaikan. (Detik, 2019)

Sumber konflik tersebut bisa berasal dari perbedaan ideologi, teologi, dan bahkan karena intervensi asing yang semuanya dapat membahayakan keutuhan negara, keutuhan wilayah, dan keselamatan segenap penduduk yang tinggal di Indonesia (Aziz, 2019). Selain itu dalam setiap konflik sosial, selalu ada karakteristik dan persoalan-persoalan yang berbeda diantara satu dengan yang lain, yang ini berhubungan erat dengan budaya lokal, doktrin dan norma, dan keadaan psikologi masyarakat dimana konflik sosial itu terjadi. Sehingga tidak dapat dilakukan generalisasi, terutama berkaitan dengan metode resolusi konflik. Suatu metode mediasi mungkin saja cocok digunakan dalam penyelesaian suatu kasus konflik sosial, akan tetapi bisa jadi tidak akan cocok digunakan pada kasus konflik sosial lainnya, terutama untuk konflik sosial yang dilatarbelakangi agama dan kemudian dibalut oleh unsur etnisitas.

Pada dasarnya sebagaimana hasil penelitian yang dilakukan oleh Ubbe (2011), bahwa konflik sosial tidak serta merta terjadi kecuali diawali dengan adanya potensi yang mengendap di dalam masyarakat dan kemudian berkembang, memanas, menjadi ketegangan, dan pada akhirnya memuncak menjadi konflik fisik sebagai akibat dari adanya pemicu. Konflik mengandung spektrum pengertian yang luas. 
Dilihat dari bentuknya, konflik dapat dibagi menjadi dua yaitu konflik horizontal dan vertikal. Konflik horizontal adalah konflik yang dilatarbelakangi oleh faktor perbedaan ideologi politik, agama dan keyakinan, ekonomi, dan faktor primordial. Sedangkan konflik vertikal adalah konflik antara negara dengan masyarakat, seperti seperatisme, dan terorisme.

\section{Berdasarkan latar belakang} diatas, penelitian ini ingin mendalami konflik keagamaan yaitu mengenai peran pemerintah daerah Aceh dalam penanganan konflik keagamaan antar mazhab Islam. Konflik antar mazhab Islam di Aceh bisa digolongkan sebagai konflik horizontal yang wujudnya terlihat dari pertikaian antar umat Islam yang berlainan mazhab (Alkhaidar, 2015). Mazhab Islam maksudnya adalah suatu kelompok muslim yang memiliki cara peribadatan dan pandangan yang sama dalam memahami Islam.

Kesamaan peribadatan dan pandangan tersebut merupakan akibat dari faktor-faktor seperti referensi bacaan yang sama, tradisi Islam yang diwarisi terus menerus hingga membudaya dalam masyarakat, dan juga karena tokoh karismatis panutan yang menjelma dalam sosok teungku, ustadz, abusyik, kyai, syaikh, dan wali (Zukhdi, 2017). Identitas tersebut melahirkan mazhab Islam yang memiliki keinginan teguh untuk mempertahankan paham, dan juga menyebarkannya kepada pihak lain. Identitas mazhab tersebut juga melahirkan paham kita dan mereka. Kita adalah saudara, mazhab yang lebih benar, sedangkan mereka adalah pihak luar yang berbeda dari kita, kurang benar dan seringkali salah. Jika tidak dibekali dengan sikap toleransi, kerelaan untuk menerima perbedaan dalam hidup, identitas mazhab menjadi benih-benih pemicu konflik. (Kamaruzzaman, 2016)

Dalam konteks Aceh, kuatnya identitas primordial mazhab Islam, kita dan mereka, menjelma dalam kasus-kasus pergantian kepengurusan mesjid secara paksa yang kadang diasosiasikan sebagai kasus perebutan mesjid. Kasus pergantian pengurus mesjid besar kabupaten Bireun sebelum tahun 2010, kasus Mesjid Baiturrahman kota Banda Aceh tahun 2015 (Alkhaidar, 2015), kasus Mesjid Pulo Raya kecamatan Beurenun kabupaten Pidie tahun 2015, kasus percobaan pergantian 
pengurus mesjid al-Izzah Kruengmane, dan kasus mesjid Alfitrah daerah Ketapang kota Banda Aceh pada permulaan tahun 2019 (Husni, 2019) adalah diantara sekian kasus konflik keagamaan yang dilatarbelakangi oleh fanatisme mazhab.

Konflik yang membawa isu agama umumnya berpotensi menjadi konflik yang sulit diselesaikan dan berlangsung lama. Selain itu, bisa menjadi lebih rumit apabila konflik atas dasar keyakinan keagamaan tersebut melibatkan isu etnisitas atau sering disebut dengan istilah ethnoreligious conflict (Raharjo, 2015). Karenanya menjadi relavan untuk mempertanyakan peran pemerintah daerah Aceh dalam menangani konflik keagamaan antar mazhab Islam. Peran pemerintah daerah tersebut diperkuat dengan terbitnya Peraturan Pemerintah Nomor 2 Tahun 2015 tentang Peraturan Pelaksanaan Undang-Undang Nomor 7 Tahun 2012 tentang Penanganan Konflik Sosial. Peraturan Pemerintah ini mengatur berbagai ketentuan mengenai pencegahan dini konflik, tindakan darurat penyelamatan dan perlindungan korban, bantuan penggunaan dan kekuatan militer, pemulihan pasca konflik, peran aktif masyarakat dalam pencegahan dan penanganan konflik, pendanaan penanganan konflik, dan monitoring dan evaluasi konflik. Pada dasarnya tujuan penelitian ini adalah untuk melihat dan mengutarakan secara konprehensif tentang peran pemerintah daerah Aceh, sebagaimana diutarakan di atas, dalam menangani konflik keagamaan antar mazhab Islam yang ditinjau dari sisi de jure dan de facto.

\section{B. PERMASALAHAN}

Penelitian ini ditujukan untuk menjawab pertanyaan tentang peran pemerintah daerah Aceh dalam upaya penanganan konflik keagamaan antar mazhab Islam. Pendekatan yang digunakan dalam penelitian ini adalah pendekatan kualitatif. Metode penelitian yang digunakan adalah hukum normatif-empiris. Penelitian hukum normatif merupakan penelitian kepustakaan (library research) yang digunakan untuk memperoleh datadata berupa dokumen hukum, baik yang berupa peraturan perundangundangan, hasil penelitian sebelumnya, buku-buku dan tulisantulisan yang berkaitan dengan pokok permasalahan yang diteliti. Salah satu 
ciri dari penggunaan pendekatan normatif yaitu melalui analisis terhadap norma-norma terkait yang berlaku. Pendekatan normatif ini dipandang relavan guna menilai sejauhmana norma-norma yang berlaku masih mampu mengakomodasi permasalan dan kondisi yang terjadi.

\section{PEMBAHASAN}

\section{Konflik Sosial Keagamaan}

Kata konflik berasal dari bahasa latin configere yang berarti saling memukul. Secara istilah konflik dapat didefinisikan sebagai suatu pertentangan atas kepentingan, tujuan, dan pemahaman antara dua pihak atau lebih. Suatu konflik akan menjadi permasalahan serius apabila pertentangan tersebut menimbulkan perebutan hak, pembelaan dan perlawanan terhadap hal yang dilanggar, atau tuntutan terhadap kewajiban dan tanggungjawab (Ubbe, 2011).

Secara sosiologis, konflik diartikan sebagai suatu proses pertentangan sosial antara dua orang atau lebih (bisa juga kelompok) dimana salah satu pihak berusaha menyingkirkan pihak lain dengan menghancurkannya atau membuatnya tidak berdaya (Sosiawan, 2015). Sedangkan konflik keagamaan bisa didefinisikan sebagai pertentangan sosial antara dua orang atau lebih yang membawa doktrin agama sebagai alasan konflik.

Konflik dilatarbelakangi oleh perbedaan ciri-ciri yang dibawa individu atau komunitas dalam suatu interaksi. Perbedaan-perbedaan tersebut diantaranya bisa karena perbedaan agama, nilai, norma, ciri fisik, kepandaian, adat istiadat, dan lain sebagainya. Dengan dibawasertanya ciri individu atau komunitas dalam suatu interaksi sosial, maka terjadinya konflik merupakan suatu yang wajar dimana jika dilihat tidak ada satu masyarakat pun di dunia ini yang tidak pernah mengalami konflik baik antar anggotanya atau dengan komunitas lain. Sehingga konflik hanya akan hilang dengan hilangnya masyarakat itu sendiri. (Aspen, 1995)

Dalam komunitas muslim sebagai contoh, terdapat begitu banyak mazhab atau kelompok muslim yang dalam beberapa segi memiliki ciri khas yang berbeda dengan komunitas muslim lain, misalnya yang paling terlihat 
perbedaanya antara muslim sunni dengan muslim syiah, akan tetapi dikalangan internal muslim sunni pun masih terdapat perbedaan-perbedaan, tergantung mazhab yang diikuti (Hanafi, Maliki, Syafii, dan Hambali). Dalam perbedaan-perbedaan itu, benih-benih konflik muncul, seperti perasaan tidak senang melihat perbedaan di kelompok lain, klaim kebenaran, dan unsur mayoritas minoritas. Semua itu bisa berujung pada konflik keagaamaan jika tidak dilakukan upaya-upaya pembinaan, singkatnya pembinaan sikap untuk menerima perbedaan dalam hidup atau perbedaan sebagai kodrat alam.

Menurut Ubbe (2011) Konflik dan benih konflik yang dapat dikontrol akan melahirkan integrasi, sebaliknya integrasi yang tidak sempurna, tidak bisa menerima perbedaan, dapat melahirkan konflik. Dalam menangani suatu konflik sosial upaya memilih resolusi konflik yang bersesuaian dengan karakteristik konflik sosial sangat penting. Resolusi konflik berasal dari bahasa inggris yaitu conflict resolution. Menurut Fisher (2001), resolusi konflik dapat didefinisikan sebagai usaha untuk menangani sebab-sebab konflik dan berusaha membangun hubungan baru yang bisa bertahan lama diantara kelompok-kelompok yang berseteru.

Menurut Ubbe (2011), resolusi konflik yang paling efektif adalah resolusi konflik yang diinisiasi oleh pihak yang berseteru, akan tetapi resolusi konflik jenis ini jarang terjadi, jika pun terjadi akan membutuhkan jangka waktu yang lama sampai inisiasi resolusi konflik itu terjadi. Karenanya dari pada menunggu hal tersebut, sangat efektif jika ada pihak ketiga sebagai interfensi yang menjadi penengah, atau inisiator resolusi konflik. Pemerintah sebagai pemegang otoritas adalah pihak intervensi yang paling efektif dilihat dari peran dan kewenangannya; sebagai pelaksana dan pembuat kebijakan, disamping sebagai pelayanan publik. Upaya-upaya seperti membuat forum lintas agama, lintas suku, dan budaya adalah diantara kegiatan yang dapat membuka mata masyarakat tentang pentingnya hidup dengan saling tenggang rasa menghormati satu sama lain.

Di Indonesia peran penting dan kewenangan pemerintah dalam penanganan konflik tersebut dapat dilihat misalnya dalam Peraturan 
Pemerintah Nomor 2 Tahun 2015

tentang Peraturan Pelaksanaan

Undang-Undang Nomor 7 Tahun 2012 tentang Penanganan Konflik Sosial. Peraturan Pemerintah ini mengatur berbagai ketentuan mengenai pencegahan dini konflik, tindakan darurat penyelamatan dan perlindungan korban, bantuan penggunaan dan kekuatan militer, pemulihan pasca konflik, peran aktif masyarakat dalam pencegahan dan penanganan konflik, pendanaan penanganan konflik, dan monitoring dan evaluasi konflik.

\section{Regulasi Kerukunan Umat Beragama di Aceh}

Pada dasarnya semua Qanun yang berhubungan dengan Syariat Islam di Aceh adalah bagian dari implimentasi keistimewaan yang diberikan oleh pemerintah pusat. Sejarah keistimewaan Aceh tersebut bergulir dalam waktu yang panjang sebagaimana telah diutarakan dalam banyak kajian. Setidaknya terdapat beberapa dasar yuridis tentang keistimewaan Aceh tersebut. Pertama adalah Undang-Undang No. 44 Tahun 1999 tentang Penyelenggaraan Keistimewaan Aceh dimana dalam Pasal 4 ayat 1 disebutkan bahwa penyelenggaraan

kehidupan beragama di Daerah Aceh diwujudkan dalam bentuk pelaksanaan syariat Islam bagi pemeluknya dalam bermasyarakat. Kemudian pada tanggal 9 Agustus 2001 diundangkan pula UU No. 18 Tahun 2001 tentang Otonomi Khusus bagi Provinsi Daerah Istimewa Aceh sebagai Provinsi Nanggroe Aceh Darussalam. Pelaksanaan dari UU Nomor 18 Tahun 2001 diatur dalam Qanun di NAD yang dapat mengesampingkan peraturan perundangan yang lain dengan mengikuti asas lex specialis derogat legi generaly yaitu peraturan perundang-undangan yang bersifat khusus mengalahkan peraturan perundang-undangan yang bersifat umum sehingga ketentuan KUHP yang bersifat umum dapat dikalahkan dengan peraturan yang lebih khusus sebagaimana yang diatur dalam Pasal 103 KUHP. Keistimewaan Aceh tersebut semakin diperkokoh dengan lahirnya UU No. 11 Tahun 2006 tentang Pemerintahan Aceh.

Dasar yuridis tersebut dalam pandangan banyak ahli menjadi landasan untuk semua Qanun Syariat yang terdapat di Aceh. Meskipun dalam banyak kasus, terdapat pihakpihak yang mempertanyakan konsistensi qanun-qanun yang 
terdapat di Aceh dengan aturan hukum yang lebih tinggi. Misalnya menurut ICJR (Institute For Criminal Justice Reform) (2014) saat menanggapi Qanun tentang penerapan Qanun Jinayat di Aceh dikatakan bahwa Qanun tersebut bertentangan dengan Undang-Undang yang lebih tinggi terutama KUHP. Karena itu, beberapa pihak telah mengajukan yudicial review untuk membatalkan sejumlah qanun di Aceh, akan tetapi sejauh peninjauan peneliti berakhir gagal. Alasan Mahkamah Agung menolak gugatan tersebut karena qanun-qanun syariat di Aceh bersifat khusus dan kekhususannya tersebut diberikan oleh Undang-Undang.

Disamping hal tersebut, issue bahwa Qanun-Qanun Syariat Islam di Aceh bertentangan dengan hak asasi manusia juga sering digunakan para pengkritik karena penilaian bahwa Qanun Syariat tersebut merendahkan harkat dan martabat manusia. Penghormatan pada Hak Asasi Manusia pada dasarnya adalah penghormatan pada kodrat dasar manusia. Hak-hak dasar itu sebagaimana di deklarasikan dalam Human Right Declaration pada 1948 oleh Persatuan Bangsa-Bangsa dipilah dibagi dalam 6 (enam) hak dasar yaitu personal right, political right, legal political right, property right, procedural right, dan social cultural right. Enam hak dasar tersebut mencakupi banyak hak lainnya sebagai cabang, seperti personal right yang didalamnya terkandung hak kebebasan berpendapat, hak kebebasan untuk berpindah tempat, dan hak kebebasan untuk memilih dan menjalankan agama atau keyakinan. Akan tetapi dalam konteks kajian hukum positif, dimaklumi bahwa hukum memang disusun untuk membatasi hak-hak individu guna menjamin hak individu lain, masyarakat, dan kepentingan umum tertentu yang dirasa lebih penting. Sebagai contoh hukuman pidana penjara untuk pencuri adalah bertentangan dengan hak asasi manusia karena mengekang kebebasan individu untuk bebas melakukan apapun yang diinginkannya, akan tetapi ditolerir sebagai sanksi atas perbuatan salah dan merusak ketentraman sosial yang telah dilakukan individu bersangkutan. Karena itu mempertanyakan bahwa suatu hukum bertentangan dengan hak asasi manusia adalah sama dengan 
mempertanyakan keabsahan negara sebagai penjamin hak asasi manusia.

Selain dari itu dalam kajian hukum positif terdapat ketentuan bahwa setiap hukum yang telah diundang-undangkan wajib diberlakukan sampai ada aturan lain yang mengatakan sebaliknya. Sebagai hasilnya bahwa kadangkala hukum yang dibuat tersebut bertentangan dengan norma-norma lain yang dikenal, misalnya norma adat, dan norma agama. Untuk menyelesaikan persoalan yang mungkin terjadi tersebut, sebagian negara memberikan hak untuk melakukan pengujian hukum, misalnya di Indonesia terdapat prosedur yudicial review yang boleh diajukan oleh siapapun warga negara indonesia sebagai upaya mempertanyakan apakah suatu undang-undang mengalami cacat hukum, baik karena alasan bertentangan dengan UUD 1945, atau saling bertolak belakang dengan hukum yang sama tingkatannya atau alasan lainnya.

Pembahasan tentang apakah hukum menjunjung keadilan atau harus bersesuaian dengan keadilan yang telah dikenal oleh masyarakat dimana hukum itu berlaku adalah pembahasan lama yang ditemukan dalam perdebatan para filosof seperti dalam Republika karya Plato. Para ahli hukum sebagian besar akan mengatakan bahwa hukum positif memiliki normanya sendiri dikenal dengan norma hukum. Meskipun pada awalnya saat suatu hukum dirancang ia sedapat mungkin disusun dengan mempertimbangkan norma yang hidup dalam masyarakat supaya tidak terjadi bias.

Prosedur demikian misalnya dikenal dalam penyusunan hukum di Indonesia bahwa sebelum suatu rancangan Undang-Undang dibuat maka diperlukan suatu kajian ilmiah berupa naskah akademik yang berisi pertimbangan-pertimbangan norma lain yang ada dalam masyarakat. Walaupun untuk negara seperti Indonesia yang majemuk akan timbul pertanyaan lainnya yaitu norma yang mana yang akan digunakan sebagai dasar penyusunan hukum. Belum lagi persoalan lain sebagai akibat dari sistem demokrasi bahwa hukum adalah resultance politic atau kesepakatan politik karena suatu rancangan undang-undang misalnya baru dapat disahkan ketika terpenuhi sekian persen suara dari anggota legeslatif. Jadi kesimpulannya 
mengenai penjelasan diatas tentang pertentangan norma hukum dan hak asasi manusia hanya dapat diselesaikan oleh hukum itu sendiri. Pun hak-hak asasi manusia yang dikenal hari ini adalah hak-hak asasi manusia yang dirumuskan dalam suatu undang-undang sehingga ia memiliki kepastian hukum.

Contoh realitas dari apa yang peneliti utarakan adalah suatu surat edaran, yang dikeluarkan oleh PLT gubernur Aceh pada tanggal 13 Desember 2019 yang ditujukan kepada para bupati/walikota se-Aceh, para kepala SKPA dan para kakanwil kementrian/non kementerian provinsi aceh, nomor 450/21770 tentang larangan mengadakan pengajian selain i'tiqad ahli sunnah waljamaah yang bersumber dari mazhab syafi'iyah. Dalam surat edaran tersebut disebutkan bahwa dilarang untuk diadakan pengajian/kajian selain dari i'tiqad ahlul sunnah waljamaah dan selain dari mazhab syafi'iyah.

Saat surat edaran tersebut diketahui oleh publik, berbagai tanggapan kontroversi datang, bahkan Majelis Ulama Indonesia meminta supaya surat edaran tersebut segera dicabut. Pertama menurut MUI bahwa pernyataan dalam surat edaran tersebut bertentangan dengan konsepsi ahlisunnah wal jama'ah. Jumhur ulama bersepakat bahwa siapapun yang mengikuti mazhab 4 yaitu malikiah, hanafiah, syafi'iyah, dan hanabilah masih tergolong dalam kelompok ahli sunnah wal jamaah. Bahkan sebagian ulama menambahkan sejumlah nama mazhab lain yang kurang pengikutnya sebagai bagian dari ahlu sunnah waljama'ah. Sehingga memaksakan mazhab syafi'iyah untuk masyarakat Aceh meskipun mazhab syafi'iyah adalah mazhab dominan di Aceh adalah bertentangan dengan konsep ahli sunnah wal jama'ah itu sendiri.

Selain dari itu surat edaran tersebut dapat menjadi pemicu konflik-konflik di kemudian hari. Seperti kasus konflik perebutan mesjid yang sudah beberapa kali terjadi di Aceh, contoh kasus mesjid Baiturrahman pada tahun 2015 dimana sekelompok muslim memaksakan pergantian pengurus mesjid karena pengurus mesjid yang telah ada sebelumnya tidak menjalankan peribadatan sebagaimana konsep dalam mazhab 
syafi'iyah. Kasus-kasus serupa yang terjadi berupa pergantian pengurus mesjid secara paksa, diasosiasikan sebagai perebutan mesjid, memiliki karakteristik yang sama yaitu karena mesjid yang menjadi incaran memiliki tatacara peribadatan yang sedikit berbeda dari mayoritas muslim di Aceh yang bermazhab Syafi'iyah. Dikhawatirkan dengan adanya surat edaran tersebut, secara tidak langsung menjadi alasan pembenar kepada oknum-oknum muslim yang tidak toleran untuk melakukan tindakan yang sama di kemudian hari.

Kedua dari sisi yuridis, surat edaran tersebut bertentangan dengan peraturan hukum yaitu qanun no. Tentang pedoman pelaksanaan syariat islam dimana dalam pasal disebutkan bahwa peribadatan di aceh dapat dilakukan dengan mengikuti salah satu mazhab hukum dari 4 (empat) mazhab hukum islam. Selain itu dalam qanun juga disebutkan. Pertentangan hukum antara dua jenis peraturan tersebut pada dasarnya tidak pada tingkatan yang sama dimana yang satu adalah surat edaran yang dikeluarkan oleh eksekutif, sedangkan yang lainnya merupakan peraturan daerah yang disusun oleh legeslatif di tingkat daerah.

Dalam hierarki hukum di Indonesia yang dapat dilihat dalam UU No. 12 Tahun 2011 tentang peraturan perundang-undangan, surat edaran bukan merupakan salah satu peraturan hukum dalam arti sebenarnya, melainkan ia hanya merupakan peraturan kebijakan atau peraturan perundang-undangan semu. Surat edaran tersebut pada dasarnya, berdasarkan pasal 15 hurub b Peraturan Menteri Dalam Negeri Nomor 54 Tahun 2009 tentang Naskah Dinas dilingkungan pemerintahan daerah, merupakan salah satu naskah dinas yang ruang lingkup pemberlakuannya hanya pada lingkungan pejabat atau lembaga pembuatnya. Akan tetapi sebagaimana diterangkan oleh menteri agama dalam ceramahnya di mesjid Baitur Rahman Banda Aceh pada bahwa mengenai surat edaran tersebut ia mengharapkan supaya dicabut oleh plt. Gubernur Aceh dan jika pun tidak dicabut karena berbagai alasan maka evaluasi terhadap surat edaran tersebut sepenuhnya akan dilakukan oleh Kementerian Dalam Negeri. 
Selain bertentangan dengan sejumlah Qanun tersebut di atas, surat edaran tersebut juga bertentangan dengan Fatwa MPU Aceh yang menyebutkan peribatan yang dilakukan dengan tatacara selain dari Mazhab Syafi'i dibolehkan karena semuanya masih dalam lingkup ahli sunnah wal jama'ah. Dalam hasil Muzakarah Ulama No. 24 Tahun 2015, MPU secara khusu menyinggung perbedaan-perbedaan sejumlah tata cara peribatan khusunya yang berkenaan dengan shalat jumat karena masalah-masalah tersebut dinilai sering menjadi perdebatan alot dikalangan umat Islam Aceh yang tidak jarang saling salah menyalahkan. Dalam hasil muzakarah ulama tersebut misalnya disebutkan bahwa azan dua kali pada hari jumat hukumnya sunnat, memegang tongkat pada hari jumat bagi khatib hukumnya adalah sunnat. Peneliti menilai apa yang dilakukan oleh MPU Aceh selaku lembaga keagamaan independen dibawah Pemerintahan Aceh adalah bagian dari upaya untuk menciptakan toleransi antar sesama umat Islam.

Penjelasan yang telah peneliti uraikan diatas menunjukkan bahwa Aceh telah memiliki sejumlah Qanun yang mengakomodir toleransi antar umat beragama di Aceh, khusunya antar umat islam. qanun-qanun tersebut memberi perincian yang rinci tentang kriteria perbedaan pendapat antar umat Islam yang dibolehkan. Qanun-qanun tersebut sudah semestinya menjadi pegangan utama pemerintah Aceh dan setiap umat Islam di Aceh dalam menyikapi perbedaan-perbedaan antar umat Islam. Adapun surat edaran plt Gubernur Aceh No. 450/21770 pada 13 Desember 2019 merupakan perintah yang dari segi yuridis mengalami cacat hukum sebagaimana telah peneliti uraikan.

\section{Peran Pemerintah Aceh dalam Upaya Pencegahan Konflik antar Umat Islam di Aceh}

Dalam data yang dirilis

Kemenag pada tahun 2019 didapatkan bahwa Aceh adalah daerah dengan indeks toleransi antar umat beragama paling rendah di Indonesia yaitu pada angka 60,2 dari rentang angka 1 sampai 100. Sedangkan indeks toleransi paling tinggi didapatkan oleh Papua Barat dengan skore nilai 82,1. Hasil penelitian tersebut memang dipertanyakan keakuratan datanya, terutama berhubungan dengan jumlah sample yang diambil. 
Menanggapi hasil survei tersebut, pemerintah Aceh dan berbagai organisasi di Aceh menyatakan keberatan dan mempertanyakan metode survey yang digunakan. Akan tetapi, sejauh belum ada data lain yang menunjukan sebaliknya, data survey yang dilakukan oleh kemenag dapat dijadikan sebagai rujukan dengan kesimpulan general bahwa Aceh merupakan daerah dengan indeks toleransi antar umat beragama paling rendah di Indonesia. Dengan menerima hasil survey tersebut, pemerintah Aceh dan semua elemen lembaga pemerintahan/non pemerintahan pada dasarnya akan menuju ke arah yang lebih baik dalam hal inteks kerukunan antar umat beragama. Itu dapat terjadi apabila pemerintah daerah Aceh mau meningkatkan perannya dalam pembinaan toleransi antar umat beragama di Aceh.

Jika dilihat kasus perkasus berkaitan dengan konflik sosial keagamaan di Aceh, terutama antar sesama umat Islam, sebenarnya Aceh telah berada pada posisi siaga bencana sosial. Maksudnya potensi konflik itu telah menjadi ancaman yang membahayakan masyarakat. Pertama dapat dilihat dari kasus- kasus pergantian pengurus mesjid secara paksa yang telah terjadi berulang kali di Aceh. Sebut saja diantaranya, kasus pergantian pengurus mesjid besar kabupaten Bireun sebelum tahun 2010, kasus Mesjid Baiturrahman kota Banda Aceh tahun 2015 (Alkhaidar, 2015), kasus Mesjid Pulo Raya Kecamatan Beurenun Kabupaten Pidie tahun 2015, kasus percobaan pergantian pengurus Mesjid al-Izzah Kruengmane, dan yang terbaru kasus mesjid Alfitrah daerah Ketapang kota Banda Aceh pada permulaan tahun 2019 (Husni, 2019).

Kasus-kasus pergantian pengurus mesjid secara paksa ini sebagaimana disampaikan oleh teungku Bulqaini, sekjen HUDA, saat menggerakkan masa di mesjid Baiturrahman tahun 2015 "Kita ingin mengembalikan pelaksanaan Ibadah di Masjid Raya Baiturrahman sebagaimana kejayaan Aceh di masa Kerajaan Iskandar Muda, seusai dengan Ahlus Sunnah Wal Jama'ah," (Alkhaidar, 2017). Drama pergantian pengurus mesjid secara paksa tersebut yang tidak hanya terjadi di Baiturrahman akan tetapi di sejumlah tempat lainnya di Aceh memiliki karakteristik dan tujuan yang sama. 
Pertama pergantian pengurus tersebut tidak dilakukan secara diplomatis melainkan anarkis dalam suatu moment saat massa jamaah mesjid berkumpul. Seakan ingin memberitahukan kepada kelompok islam manapun di Aceh bahwa kami tidak bisa menerima model islam bagaimanapun selain dari cara berislam yang kami lakukan.

Lebih jauh lagi drama tersebut membawa primordialisme kesukuan yang ingin mengatakan bahwa yang mereka lakukan adalah bagian dari menjaga Aceh, bahwa mereka adalah representatif dari bangsa Aceh sedangkan kelompok Islam lain adalah representasi sesuatu dari luar, bukan ciri khas dari bangsa Aceh. "Tidak ada kudeta masjid, yang kami inginkan mulai hari ini sampai kiamat nanti ibadah di Mesjid Raya Baiturrahman harus sesuai dengan apa yang tertulis dalam mazhab Syafi'i yaitu Ahlus Sunnah Wal Jamaah," ujar Tengku Bulqaini yang disambut teriakan Allahu Akbar berulang-kali dari sebagian jama'ah yang mendukung aksi heroik perebutan mimbar masjid ini. Dalam drama pergantian pengurus mesjid secara paksa pada mesjid Baiturrahman Banda Aceh tahun 2015 dimulai dengan kerumunan massa yang memaksa khatib Jum'at yang sedang berkhutbah di Baiturrahman untuk memegang tongkat dan meminta azan dilakukan sebanyak dua kali sebagaimana umum dilakukan di mayoritas mesjid di Aceh. Sebagaimana ditulis oleh Alkhaidar bahwa perebutan mesjid tersebut telah direncanakan oleh sejumlah organisasi Islam di Aceh diantaranya Himpunan Ulama Dayah Aceh (HUDA), Majelis Ulama Nanggroe Aceh (MUNA), dan Front Pembela Islam (FPI) (Akhaidar, 2017).

Sejatinya peran pemerintah Aceh dalam menyikapi konflik keagamaan antar umat Islam di Aceh, adalah dengan melakukan dua hal. Pertama, pemerintah Aceh perlu konsisten menjalankan setiap aturan hukum berupa qanun yang berhubungan dengan kerukunan umat beragama. Hal tersebut untuk memberikan kepastian hukum kepada muslim yang ada di Aceh. Selain dari itu fatwa MPU dan hasil Muzakarah MPU Aceh, selaku lembaga keagamaan rsmi yang bertugas memberi masukan kepada pemerintah dan kepada masyarakat, patut menjadi dasar bagi pemerintah dalam mengeluarkan suatu qanun, 
bahkan sampai aturan yang berbentuk surat edaran. Kedua, forum-forum kerukunan antar umat Islam perlu diinisiasi oleh pemerintah dimana berbagai kelompok mazhab Islam di Aceh dapat berkumpul, saling bertukar pikiran, atau setidaknya saling kenal membentuk hubungan persaudaraan. Disamping itu pemerintah perlu menggalakkan kegiatan-kegiatan perlombaan untuk lintas santri dayah, baik perlombaan karya tulis atau lainnya yang isi mengandul muatan toleransi antar umat beragama, antar umat Islam khususnya. Dan yang paling penting dari itu, meskipun secara individu pemerintah merupakan seorang muslim dari mazhab Islam tertentu atau mendukung kelompok tertentu, pemerintah tidak dapat menjadikan keyakina induvidu tersebut menjadi dasar menghakimi mazhab Islam lain di Aceh, seperti yang terlihat dalam surat yang dikeluarkan oleh Gubernur tersebut.

\section{PENUTUP}

Dari uraian panjang yang telah peneliti uraikan dalam penelitian ini, ada dua hal yang dapat disimpulkan, yaitu:
1. Bahwa Aceh telah memiliki regulasi yang berhubungan dengan toleransi antar umat beragama, khususnya regulasi-regulasi yang mengatur tentang peribatan, hukum, dan aqidah yang dibolehkan. Dalam hal keagamaan untuk muslim di Aceh, Pemerintah Aceh sebagai wujud dari mendengar aspirasi masyarakat hanya menyetujui aliran-aliran islam yang berhaluan ahlu sunnah wal jamaah yaitu aliran yang mengikuti mazhab Syafi'iyah atau setidaknya masih dalam lingkup 4 (empat) mazhab hukum Islam; Malikiah, Hanafiah, dan Hanabilah. Selain dari 4 mazhab tersebut, terutama kelompok Syiah dianggap sebagai kelompok yang ilegal. Selain dari itu, Aceh terbuka untuk organisasi-organisasi Islam nasional seperti Nadhatul Ulama, Muhammadiah, Persis, dll. Dalam pemberlakuan hukum Islam di Aceh terutama untuk aturanaturan yang secara teks bertentangan dengan hukum yang lebih tinggi tingkatannya, berlaku ketentuan lex specialis deroget legy generalis s. Untuk surat edaran yang dikeluarkan oleh PLT Gubernur Aceh sebagaimana 
tersebut, maka menurut kajian hukum yang telah peneliti lakukan dapat disimpulkan isi dari surat edaran tersebut bertentangan dengan peraturan daerah (Qanun), sehingga surat edaran tersebut yang statusnya dalam hukum di Indonesia hanyalah salah satu dari surat dinas sudah semestinya dicabut oleh pemerintah Aceh.

2. Konflik-konflik keagamaan antar mazhab Islam di Aceh yang terbaca dan terlihat dari kasus-kasus perebutan mesjid terjadi karena tokoh-tokoh agama belum bisa menerima kelompok lain selain syafi'iyah menjadi pemimpin agama di mesjid-mesjid. Dalam pandangan tokoh ulama dan santri Aceh, Ahlul Sunnah wal Jamaah di Aceh harus diasosiasikan dengan mazhab Syafi'i dalam bidang hukum, dan mengikuti imam Asy'ary dalam bidang akidah atau yang sejalan dengannya. Sehingga tidak diperkenankan mesjidmesjid untuk dikelola oleh kelompok yang berpahaman atau mengikuti mazhab selain dari tersebut. Terlebih dalam pandangan tokoh agama Aceh, mesjid adalah pusat sentral Islam dan memberikan ciri khas keagamaan bagi suatu wilayah, dimana tokoh-tokoh agama Aceh menginginkan supaya Aceh menjadi daerah yang memiliki ciri khas bermazhab Syafi'i. Pada dasarnya tokoh-tokoh agama di Aceh tidak melarang segala bentuk tata cara keagamaan Islam selain dari mazhab Syafi'i, asalkan masih dalam lingkup 4 mazhab hukum. Akan tetapi khusus untuk seluruh mesjid di Aceh supaya dikelola oleh kelompok mazhab Syafi'iyah. Meskipun dalam Qanun dan fatwa MPU Aceh dan hasil Muzaqarah Ulama Aceh dengan terang disebutkan kebolehan mengikuti mazhab selain Syafi'iyah. Peran pemerintah dalam hal ini mengikuti keinginan mayoritas, yang terlihat dari keluarnya surat edaran PLT Gubernur pada Desember 2019 tentang larangan melakukan pengajian dan peribadatan selain dari mazhab Syafi'iyah.

\section{DAFTAR PUSTAKA}

Ahmad, H, A. (2016). Resolusi Konflik Keagamaan di Aceh Singkil dalam Perspektif Budaya Dominan. Jurnal Multikulturan dan Multireligious, 15 (3), 45-59. 
Alchaidar.(2015). Menyoal Benturan Antar Mazhab di Aceh. Web: https://Aceh.tribunnews.com/201 5/06/26/menyoal-benturanantarmazahab-di- Aceh.

Aziz, A. (2019). Transformasi Konflik dan Peran Pemerintah Daerah. Journal of Urban Sociology, 2 (1), 28-41

BPPB, 2012, Kamus Besar Bahasa Indonesia, web: https://kbbi.web.id/peran

Husni, F. (2019). Aksi Pemukulan Juga Sempat Terjadi di Dalam Mesjid Alfitrah.

https://www.ajnn.net/news/aksipemukulan-juga-sempat-terjadidi-dalam-masjidalfitrah/index.html.

Kamaruzzaman, B, A. (2016). Memahami Potensi Radikalisme dan Terorisme di Aceh. Aceh : Bandar Publishing.

Meilisa,H.(2019). Ada Empat bencana Sosial di

Qanun No. 6 Tahun 2014 tentang Jinayat

Raharjo, I, N, S. (2015). Peran Identitas Agama Dalam Konflik di Rakhine Myanmar Tahun 2012-2013. Jurnal Kajian Wilayah, 6 (1), 3551

Raharjo. M.(2017). Studi Kasus Dalam Penelitian Kualititaf: Konsep dan Bentuknya. Malang: Universitas Islam Negeri Maulana Malik Ibrahim.

Rahma,

A.

(2019).

Mab

es Polri Catat ada 26 Konflik Sosial Sepanjang 019. https://nasional.tempo.co/read/1 285460/mabes-polri-catat-ada26-konflik-sosial- sepanjang-2019
Raho, B. (2007). Teori Sosiologi Modern. Jakarta: Prestasi Pustaka.

Sosiawan, U, M. (2015). Penelitian Hukum tentang Mekanisme Penyelesaian Konflik antar Negara dalam Pengelolaan Sumber Daya Kelautan. Jakarta : BPHN Kementrian Hukum dan Ham RI.

The Aspen Institute. (1997). Managing Conflict in the Post-Cold War World: the Role of Intervention. The Prosiding of the Aspen Institute Conference on International Peace dan Security. August 2-6. Colorado : Aspen.

Ubbe, A. (2011). Pengkajian Hukum tentang Mekanisme Penanganan Konflik Sosial. Jakarta : BPHN Kementrian Hukum dan Ham RI.

Undang-Undang No. 23 Tahun 2014 tentang Pemerintahan Daerah

Zukhdi, M. (201). Dinamika Perbedaan Mazhab dalam Islam. Jurnal tahun

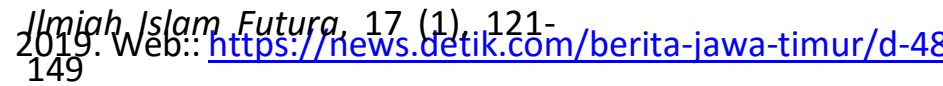

